\title{
Chapter 7 \\ Reconciling Boserup with Malthus: Agrarian Change and Soil Degradation in Olive Orchards in Spain (1750-2000)
}

\author{
Juan Infante-Amate, Manuel González de Molina, Tom Vanwalleghem, \\ David Soto Fernández and José Alfonso Gómez
}

Keywords Long-term socio-ecological research · Southern Spain · Agricultural change

\subsection{Introduction}

Soil degradation is one of the consequences of farming activity that has had the greatest impact on the capacity of agro-ecosystems to produce food and offer environmental services. ${ }^{1}$ This risk is threatening the Mediterranean basin as one of the principal factors of non-sustainability (Kirkby et al. 2004). Unintended, long-term consequences of different land use practices are some of the primary drivers of

\footnotetext{
${ }^{1}$ According to the FAO (1995, p. 6): "The concept of land degradation refers to the deterioration or total loss of the productive capacity of the soils for present and future use (...). Such loss occurs mainly because of various forms of erosion (by wind and water) and of chemical and physical deterioration."
}

J. Infante-Amate $(\bowtie) \cdot$ M. G. de Molina $\cdot$ D. S. Fernández

Agro-ecosystems History Laboratory, University Pablo de Olavide,

Carretera de Utrera km.1, 41013 Sevilla, Spain

e-mail: jinfama@upo.es

M. G. de Molina

e-mail: mgonnav@upo.es

T. Vanwalleghem

Department of Agronomy, University of Córdoba,

Carretera Madrid Km 396, 14071 Córdoba, Spain

e-mail: tom.vanwalleghem@uco.es

D. S. Fernández

e-mail: dsotfer@upo.es

\section{J. A. Gómez}

Instituto de Agricultura Sostenible, CSIC, Av. Menéndez Pidal s/n, Campus Alameda del Obispo Apartado 4084, 14080 Córdoba, Spain

e-mail: joseagomez@ias.csic.es 
socio-ecological change for Mediterranean soils, rooted in the process of productive intensification that agro-ecosystems have been undergoing for several centuries (McNeill 1992). In recent decades, the expansion of olive growing has exacerbated the problem in the Mediterranean region (Beaufoy 2001; Gómez et al. 2008). Although the natural phenomena responsible for the process of soil degradation seem clear, debate remains regarding its social causes (FAO 1995). The centenary of the birth of Ester Boserup — and the debate that has grown regarding her work-offers a good opportunity to examine this issue further.

The primary objective of this chapter, based on the evidence of severe degradation of Mediterranean soils, is to analyse its historic dimension through a case study performed in a mountainous area of southern Spain (Montefrío, Granada), in which to identify the causes and thereby contribute to the on-going debate regarding management approaches and soil degradation on a global scale, where the work of Boserup has been so influential.

Our case study, which spans two and a half centuries (1750-present day), examines whether population growth was among the primary factors in the transformation from pre-industrialised to industrialised agriculture, with its consequent environmental impacts. In the light of the transition towards sustainable agriculture, understanding the vital role played by population size and dynamics is crucial, especially if approached on a global scale (Haberl et al. 2011), given that the population of the planet is constantly growing (United Nations 2007).

In the text, we first present our case study in its environmental and social context. Then, we continue explaining the character of agrarian change in the southern Spain and our local case study focusing on both social and material aspects to contextualise the causes of soil degradation through a historical perspective. We then provide data and context regarding the problem of soil degradation in our case study. Finally, we conclude by discussing the impacts of agrarian change on soil degradation from the middle of the eighteenth century to the present by quantifying soil erosion in olive orchards and nutrient balances.

\subsection{Case Study in the Mountains of Southern Spain}

Our case study is situated in the Mediterranean mountains of southern Spain, in the province of Granada. The 25.5- $\mathrm{km}^{2}$ study area is part of the Baetic Cordillera chain; the average gradient is $10 \%$, representing a typical example of mid-height mountain agriculture. The climate in this area is Mediterranean-Continental, with average annual rainfall of $550 \mathrm{~mm}$, an average annual temperature of $15.2^{\circ}$ and potential evapotranspiration (PET) of $760 \mathrm{~mm}$. The soil type is primarily Calcic Cambisol according to the FAO classification. Montefrío, our case study, is a town with a long olive-growing tradition, and its geographical and soil and climatic characteristics are similar to those of the agricultural interior of Andalusia. Until well into the twentieth century, it was fairly isolated because of the characteristics of its relief; hence, its processes of change are an attractive field of study. 
This location was specifically chosen for its territorial representativeness and the availability and quality of its historic documentation. Furthermore, some of the authors of this paper have conducted previous research regarding Montefrío, which has proved immensely useful. This research has provided information needed to ascertain the agrarian evolution of the town and of olive-growing in particular (Infante-Amate 2011), the balance of nutrients (González de Molina et al. 2010) and erosion over time from a historical perspective (Vanwalleghem et al. 2011).

\subsection{From a Pastoral System to a Specialisation in Olive Production}

\subsubsection{Agrarian Change in Preindustrial Agriculture}

In the mid-eighteenth century, Montefrío had 5,108 inhabitants, a scant population in comparison with other territories in northern Spain ( 23 inhabitants $/ \mathrm{km}^{2}$ ), with high land availability, in excess of 4 ha per inhabitant. Land use was primarily devoted to livestock, offering future possibilities for the agricultural "colonisation" of the town. It was, as Herman Daly said (2005), an "empty" territory where labour, rather than resources, was the main limiting factor.

Land use was organised according to different levels of labour intensity. Land occupation occurred was based on a primary population nucleus and on small population clusters known as cortijos scattered throughout the municipality. Cultivation decreased in intensity with distance from these clusters. ${ }^{2}$ The land that surrounded the town (ruedos) was cultivated intensively because more labour could be applied there. Some areas had access to irrigation and thus were where fruit, vegetables, cereals and leguminous crops were grown. The available manure was dedicated if possible to these lands because of the transport economy and because the costs in labour could be easily borne by the town (for more details, see González de Molina et al. 2010; Infante-Amate 2011) (Table 7.1).

The majority of the cultivated land $(28.8 \%)$ where "al tercio" (wheat/fallow/ fallow) rotation was practised was located adjacent to this area, with fairly modest sowing and harvesting. Finally, grape vines and olive trees, which received low levels of labour during this period, occupied a marginal area $(0.7 \%)$, and their products provided subsistence for the locals. The land area dedicated to permanent, natural pasture $(51.1 \%)$ reveals that a very significant portion of the agro-ecosystem remained uncultivated, as home to significant livestock numbers $\left(21 \mathrm{LU} / \mathrm{km}^{2}\right)$.

In accordance with the tradition inaugurated by Marshall Sahlins (1972), Montefrío appeared as a kind of "opulent society", which, through high levels of labour productivity, was able to feed a scant population more effectively. Indeed, the available food per capita in $1750 \mathrm{had}$ a higher energy content than in the nineteenth century

\footnotetext{
${ }^{2}$ In a similar model to that formalised by Von Thünen and, more recently, this has been taken up again by the field of Economic Geography (Fujita et al. 1999).
} 
Table 7.1 Evolution of the agro-ecosystem in Montefrío, 1750-2000. (Source: González de Molina et al. 2010; Infante-Amate 2011)

\begin{tabular}{|c|c|c|c|c|c|c|}
\hline & Unit & 1750 & 1850 & 1900 & 1950 & 2000 \\
\hline Population & [no.] & 5108 & 7938 & 10404 & 13698 & 6453 \\
\hline Population density & {$\left[\mathrm{inhab} / \mathrm{km}^{2}\right]$} & 23.36 & 38.16 & 45.40 & 52 & 27 \\
\hline Cereal & [ha] & 7372 & 12940 & 15245 & 15894 & 2165 \\
\hline Anпиаl & [ha] & 0 & 0 & 0 & ? & 2165 \\
\hline Ruedo ${ }^{\mathrm{a}}$ & [ha] & 24 & 1324 & 2934 & ? & 0 \\
\hline Tercio $^{b}$ & [ha] & 7348 & 11616 & 12311 & $?$ & 0 \\
\hline Fruit and vegetables & [ha] & 71 & 170 & 97 & 217 & 35 \\
\hline Olives & [ha] & 120 & 442 & 718 & 2320 & 15006 \\
\hline Vines & [ha] & 59 & 196 & 246 & 44 & 4 \\
\hline Cultivated & [ha] & 7622 & 13748 & 16306 & 18475 & 17210 \\
\hline Mountain & [ha] & 10100 & 3110 & 3110 & 5920 & 4046 \\
\hline Pasture & [ha] & 3025 & 2840 & 2439 & 712 & 1366 \\
\hline Utilised agricultural area & [ha] & 20747 & 19698 & 21855 & 25107 & 22622 \\
\hline Unproductive & [ha] & 1060 & 1060 & 1060 & 1060 & 910 \\
\hline Total & [ha] & 21807 & 20758 & 22915 & 26167 & 23532 \\
\hline Livestock for Income $^{c}$ & [LU] & 3326 & 880 & 400 & 1830 & 1225 \\
\hline Livestock for Labour $^{\mathrm{d}}$ & [LU] & 1821 & 1012 & 1187 & 2356 & 200 \\
\hline Total Livestock & [LU] & 5147 & 1892 & 1587 & 4187 & 1425 \\
\hline Production harvested & [t d.m.] & 3157 & 7387 & 9470 & & \\
\hline Production harvested & {$[1752=100]$} & 100 & 234 & 300 & & \\
\hline Production/inhabitants & [kg d.m.] & 618 & 931 & 910 & & \\
\hline Production/inhabitants & {$[1752=100]$} & 100 & 151 & 147 & & \\
\hline Production/cropland & [kg d.m./ha] & 153 & 537 & 581 & & \\
\hline Production/cropland & {$[1752=100]$} & 100 & 352 & 380 & & \\
\hline Average farm size & [ha] & 53.09 & 26.70 & 10.75 & 8.95 & 9.50 \\
\hline
\end{tabular}

a "Ruedo" Rotation. Four-year rotation of wheat-beans-wheat-chick peas

b "Al tercio" Rotation. Three-year rotation with 2 years fallow and one year wheat

${ }^{\mathrm{c}}$ Labour livestock. Animals involved in transport and soil management (cows, mules, horses ...)

${ }^{\mathrm{d}}$ Income livestock refers to those primarily devoted to produce food or products such as meat, milk or eggs (i.e., chickens, goats, sheep, or pigs)

(González de Molina et al. 2011). Recent anthropometric studies have shown that the biological standards of living for its inhabitants were among the highest in Spain at that time (Cámara 2007).

During the second half of the eighteenth century, population growth was practically zero; however, in barely a century, it nearly doubled to 10,101 inhabitants in $1877 .^{3}$ Following the fall of the Ancien Régime, new liberal policies facilitated access to land to a great number of landless peasants. Over the course of the nineteenth century, there were as many as three land distributions in Montefrío, which attracted significant population numbers (Martínez 1995). Other liberal measures, such as land seizure and the redemption of tithe rent charges, also facilitated access to land ownership. The availability of labour for more intensive management of

\footnotetext{
${ }^{3}$ It was primarily due to immigration and growing birth rates. More details in Cámara (2007, p. 214-220).
} 
Table 7.2 Distribution of registered land ownership, 1852-1901. (Based on Martínez 1995)

\begin{tabular}{|c|c|c|c|c|}
\hline & 1852 & & 1901 & \\
\hline & Owners & $\%$ & Owners & $\%$ \\
\hline$\overline{0-5}$ & 533 & 69.31 & 1490 & 74.31 \\
\hline $5-10$ & 64 & 8.32 & 220 & 10.97 \\
\hline $10-50$ & 90 & 11.70 & 211 & 10.52 \\
\hline $50-100$ & 30 & 3.90 & 42 & 2.09 \\
\hline $100-500$ & 49 & 6.37 & 37 & 1.85 \\
\hline Over 500 & 3 & 0.39 & 5 & 0.25 \\
\hline Total & 769 & 100 & 2005 & 100 \\
\hline & $H a$ & $\%$ & $\mathrm{Ha}$ & $\%$ \\
\hline $0-5$ & 890.18 & 4.50 & 2260.04 & 10.48 \\
\hline $5-10$ & 486.29 & 2.46 & 1539 & 7.14 \\
\hline $10-50$ & 2157.51 & 10.92 & 4537 & 21.05 \\
\hline $50-100$ & 2183.98 & 11.05 & 2872 & 13.32 \\
\hline $100-500$ & 10464.68 & 52.95 & 6599 & 30.61 \\
\hline Over 500 & 3579.85 & 18.11 & 3750 & 17.4 \\
\hline Total & 19762.49 & 100 & 21557 & 100 \\
\hline
\end{tabular}

the agro-ecosystem was greater and consequently so were the feeding requirements, which in turn spurred further reclamation and crop intensification. ${ }^{4}$

Analysing the structure of ownership and agrarian exploitation in Montefrío demonstrates that the number of small landowners increased as the number of large landowners decreased. Farms between 0 and 10 hectares in 1752 accounted for less than $3 \%$ of the land area registered on the cadastral register. One century later, this figure had increased to $7 \%$. In contrast, in the mid-eighteenth century, farms over 500 ha accounted for over $40 \%$ of all lands, whereas in 1850 this figure had fallen to $18 \%$ (see Table 7.2). A large group of peasant farmers were able to access land ownership (Martínez 1995, p. 163).

However, the population growth and the consequent increased pressure on resources were beginning to decline by the end of the nineteenth century. Indeed, the number of small landowners continued to increase through the liberal measures outlined above, and as a result of the opportunities for clearing and intensifying production, they were favoured by the egalitarian legacy characteristic of Spanish legislation. Relatively isolated from the main commercial points of the region, the town was by necessity self-sufficient. By the beginning of the twentieth century, Montefrío had over two thousand landowners. Approximately $90 \%$ of them, $40 \%$ of the registered plots of land, had fewer than 50 ha. The greatest demographic increase was recorded among landowners with insufficient land; the number of peasant farmers

\footnotetext{
${ }^{4}$ The first distribution was performed using wasteland and land from the Royal Patrimony in 1799, grounded in the seizures of wasteland by Charles III in 1769. This distribution was performed on a ground-rent basis, payable to the town hall, among 440 residents, in lots of between 1 and 10 ha. A second occurred at the end of the 1830s (1839), following another failed attempt during the Constitutional Triennium, this time, on the basis of ownership. The population increased from 6,357 inhabitants in 1819 to 7,903 in 1842 . The increasing cropland occupied former pastureland or forestland that was not previously cultivated due to low population pressure.
} 
who owned fewer than 5 ha rose from 192 in 1752 to 533 in 1852 and had reached 1,490 by 1901 , representing an approximately eight-fold increase. The average area of land owned by this segment also decreased, from 1.67 ha per owner in 1852 to 1.51 in 1901 (see Table 7.2). Certainly, the number of landowners increased at a much greater rate than did the population as a whole, but this occurred under increasingly precarious conditions because of the scarce provision of land and because the productive possibilities of this land were being exhausted. This meant increasingly difficult access to labour and to income livestock and fewer opportunities for work, which stagnated in availability. The composition of their diet also deteriorated (González de Molina et al. 2011), and anthropometric studies display a sharp decline in biological standards of living, also accompanied by waves of emigration (Cámara 2007) and increasing development of social conflict (Cruz 1994).

At the end of the nineteenth century, the amount of land dedicated to agriculture had increased to levels never before observed, and more intensive rotations occupied more space than ever before. The only way of fulfilling the dietary needs of the town was to replace livestock farming, which could only be sustainable under low population densities, with another form of agriculture based on cereal crops. This change seems to support the classic strategy described by Boserup (1965, 1981), whereby territories that begin to become densely populated intensify their rotations and increase production to adapt to the limitation. However, focusing solely on population dynamics ignores the manifest importance of the institutional dimension of change, which in this case encouraged population increases or immigration into the town and also governed the way in which the rural community was able to colonise the territory or intensify its management.

The increasingly precarious situation of the peasantry of Montefrío, given the imbalance between population and resources, explains here and elsewhere the increasingly intensive use of the land to guarantee subsistence, which led to processes of soil degradation (Blaikie and Brookfield 1987; FAO 1983).

\subsubsection{Specialisation in Olive Growing and the Major Transformation of the twentieth Century}

Olive growing is the best metaphor for the changes that have occurred in the Spanish Mediterranean in the past two centuries. It encapsulates the intensive progression of agro-ecosystems in the nineteenth century, and its level of expansion in recent years has meant that the area of land dedicated to this activity in certain territories such as Montefrío occupies the total utilised agricultural area.

In the mid-eighteenth century, olive trees were scattered in Montefrío, integrated with other uses and subject to fairly non-intensive management. Olive production barely exceeded $100 \mathrm{~kg}$ per ha, whereas production was greater than $500 \mathrm{~kg}$ by 1900. Although the production as total biomass of the tree remained relatively stable (including the use of pruned material and ground cover plants), there were increased efforts to improve olive production, which is the most valuable part of the crop. 
Human labour increased from 11 days/ha in 1750 to 28 days in 1900, and animal labour increased from $4.39 \mathrm{obradas} / \mathrm{ha}$ to $10.65 \mathrm{obradas} / \mathrm{ha}$. Although higher olive yields were obtained, total crop productivity, measured as total biomass, decreased. In spite of this, olive orchards were a good solution for peasants with insufficient land. ${ }^{5}$ In addition to olives, they provided wood and timber from pruning for domestic fuel, leaves to feed goats, ground cover plants to feed sheep, and pomace to feed livestock. In terms of energy, these products represent between 80 and $90 \%$ of the total usage (Infante-Amate 2011, 2012), and these products were decisively important for these peasant economies.

Therefore, olive orchards charted a transition from an "empty" (Daly 2005) and "opulent" (Sahlins 1972) world towards more intensive cultivation, partially linked to the market, which required more intensive labour despite the costs in productivity (Boserup 1965). This is a similar story to what the changes in land use throughout Montefrío: increased agricultural intensity based on a loss of labour productivity.

However, the major transformation of agriculture in Montefrío, as in the rest of the country, came in the second half of the twentieth century and was characterised by the industrialisation of the sector and the full expansion of olive growing. Spain joined the European Common Market in the 1980s and its agricultural policy in the early 90s while also achieving high levels of industrialisation and consolidating its integration into the global economy. The importation of great quantities of energy and materials has allowed the cultivated land area to occupy essentially the entire utilised agricultural area (Guzmán and González de Molina 2009). This socio-ecological transition in Spanish agriculture eventually isolated the processes of food production and consumption from the territory, as has also occurred in other countries (Erb et al. 2009; Würtenberger et al. 2006). ${ }^{6}$ Because of the mass importation of grain, meat consumption levels have returned to those last observed in the eighteenth century (Infante-Amate and González de Molina 2013), and land has become available for other uses. Production specialisation was accompanied by the expansion of olive growing, primarily because of the ecological advantages of this tree for development in Mediterranean climates (Angles 1999) and also because of the public subsidies of the Common Agricultural Policy (De Graaf and Eppink 1999).

Today, there are approximately 10 Mha under olive cultivation in the world, over $80 \%$ of which are in the Mediterranean basin (FAO 2013), primarily because towns such as Montefrío have focused their agrarian activity fully on the production of olive oil; approximately $90 \%$ of cultivated land is allocated to this crop, which is largely managed industrially. This latest leap towards agricultural intensification has substantially improved labour productivity (see Table 7.3). As recently discussed by

\footnotetext{
${ }^{5}$ During this period, small peasant farmers were behind the expansion of the olive orchard in southern Spain and in Montefrío in particular (see Infante-Amate 2011).

${ }^{6} \mathrm{New}$ economic processes have gradually developed between production and consumption: transportation, packaging, processing, preservation, distribution and consumption. The gap between the concept of "agrarian product", understood as the output derived from the production of the agrarian sector, and the concept of "food product", understood as the final product resulting from the transformation of agrarian products and the addition of diverse uses, has continued to grow in recent decades.
} 
Table 7.3 Indicators showing the evolution of the olive orchard in Montefrío, 1750-2000. (Source: Infante-Amate 2011)

\begin{tabular}{|c|c|c|c|c|c|c|}
\hline & Unit & 1750 & 1850 & 1900 & 1950 & 2000 \\
\hline $\begin{array}{l}\text { Land area olive } \\
\text { orchards }\end{array}$ & [ha] & 120 & 442 & 718 & 2320 & 15006 \\
\hline $\begin{array}{l}\text { Land area olive } \\
\text { orchards/utilised } \\
\text { agricultural area }\end{array}$ & {$[\%]$} & 0.58 & 2.24 & 3.29 & 9.24 & 66.33 \\
\hline Olive production & [kg d.m./ha] & 108.72 & 543.61 & 534.21 & 801.49 & 1339.18 \\
\hline Pruning production & & 675.90 & 887.50 & 710.00 & 852.00 & 710.00 \\
\hline Plant cover production & & 381.20 & 381.20 & 381.20 & 1997.71 & 0 \\
\hline $\begin{array}{c}\text { Total biomass } \\
\text { production }\end{array}$ & & 1165.82 & 1812.31 & 1625.41 & 2851.2 & 2049.18 \\
\hline $\begin{array}{l}\text { Productivity olive } \\
\text { labour }\end{array}$ & [day $/ \mathrm{kg}]$ & 9.87 & 15.61 & 19.00 & 10.35 & 72.58 \\
\hline $\begin{array}{l}\text { Productivity Total } \\
\text { labour }\end{array}$ & [day $/ \mathrm{kg}]$ & 105.89 & 52.05 & 57.82 & 36.83 & 111.07 \\
\hline Human labour & [day/ha] & 11.01 & 34.82 & 28.11 & 77.41 & 18.45 \\
\hline Animal labour & [obrada/ha] & 4.39 & 10.57 & 10.65 & 15.26 & 6.84 \\
\hline Input energy (1) & {$[\mathrm{Gj} / \mathrm{ha}]$} & 3.99 & 9.62 & 7.88 & 22.55 & 26.51 \\
\hline Total output (2) & {$[\mathrm{Gj} / \mathrm{ha}]$} & 21.98 & 31.81 & 27.95 & 46.39 & 31.52 \\
\hline Efficiency $(2 / 1)$ & {$[\mathrm{Gj} / \mathrm{ha}]$} & 5.51 & 3.31 & 3.55 & 2.06 & 1.19 \\
\hline
\end{tabular}

Fischer-Kowalski et al. (2010), the productivity of labour could once again increase in an unprecedented way because of the application of substantial amounts of energy, largely from fossil fuels.

The model of agrarian growth that accompanied the industrialisation of Spanish agriculture was based on the forced transfer through the markets of a portion of agrarian incomes (González de Molina and Guzmán 2006). This resulted from the on-going deterioration in the exchange relationship between the agrarian sector and the urban industrial and services sector. In comparison with other sectors, agrarian income suffered a significant decline in real terms. Between 1990 and 1999, income in the province of Granada - to which Montefrío belongs-had fallen by $15 \%$ (Analistas Económicos de Andalucía 2000).

Furthermore, the process by which the subsidies of Common Agricultural Policy incentivised productivity through the intensification of cultivation and through savings in labour costs is well known (De Graaf and Eppink 1999). Much of the technological package integrated into the management of olive orchards responds to the new olive-growing reality of the region, including part-time agriculture, an ageing population and a loss of profitability ${ }^{7}$, factors that are separate from the dynamics of population pressure.

\footnotetext{
${ }^{7}$ In addition to this decline in agricultural income, over the last 10 years, the group of farm owners who have another principal economic activity has increased by $30 \%$, and over the past 20 years, the percentage of farm owners aged over 64 has increased from 11.7 to $20.2 \%$ (IEA 2011).
} 


\subsection{The Impacts of Agrarian Change: The Problems of Soil Erosion and Soil Fertility}

\subsubsection{Managing Land Fertility}

The expansion of the amount of land used to produce food for human consumption was achieved at the expense of space used to grow feed for livestock (Table 7.1). Livestock numbers declined between 1752 and 1854, a trend that continued until the end of the nineteenth century. Livestock density was reduced to a third of its previous size. The expansion of cultivated land and the net increase in demand for animal traction explain why the decrease in working animals was not as marked. However, the decline was most obvious in income livestock, which were fed on products of the agro-ecosystem that could not be exploited to grow food for humans or labour livestock. By 1901, this type of livestock had fallen to just over $12 \%$ of the figure registered in 1752 .

One consequence of this process was a $54 \%$ net reduction in the fertilisation capacity of livestock. The imbalance between cultivated lands and those dedicated to animal feed, at a time when significant transportation of grain, straw or manure was limited (González de Molina 2010; Sieferle 2001), diminished fertilisation capacity. In truth, the possibilities of agrarian growth in Montefrío had reached their practical limit in the final decades of the nineteenth century. The possibilities for increasing the amount of cultivated land were very limited. In general terms, yields had begun to level off and, in some cases, even to decline. The decrease in production per inhabitant shown in Table 7.1 is explained by this fact. However, harvested biomass continued to grow during this period. How was the global increase in production between 1852 and 1901 possible, therefore? It was achieved at the expense of the nutrient reserves in the soil. The decline observed in the amount of manure applied per cultivated hectare confirms this: it was reduced to a fifth of the former levels.

In previous articles (García-Ruiz et al. 2012; González de Molina et al. 2010), we have examined the balance of nutrients on an aggregate scale and for the main types of crops. Table 7.4 provides a summary of our primary findings in this regard, showing that the extraction of nutrients exceeded inputs as crops became more intensive. In the mid-eighteenth century, the nutrient balance for crop rotations and on an aggregate scale was positive, with the exception of a few losses in potassium that were not significant because of its abundance in the soil. By the mid-nineteenth century, the balance of potassium had become even more negative, and the phosphorus balance became negative for the first time. Something similar occurred at the end of the century with perhaps the most important macronutrient in preindustrial agriculture: nitrogen (Allen 2008; Cunfer and Krausmann 2009). This was yet another symptom of the difficulties facing the agro-ecosystems of Montefrío in the final few decades of the nineteenth century: the progressive exhaustion of the possibilities for intensifying production, the mining of nutrients (González de Molina et al. 2010), the declining biological standards of living, and emigration (Cámara 2007). These processes may have spread to other areas in southern Spain (Infante-Amate 2011). 
Table 7.4 Balance of nutrients in Montefrío, 1750-1900. (Source: García-Ruiz et al. 2012; González de Molina et al. 2010)

\begin{tabular}{lrrrrrrl}
\hline & $\begin{array}{l}\text { The whole } \\
\text { town }\end{array}$ & $\begin{array}{l}\text { Fruit and } \\
\text { vegetables }\end{array}$ & Ruedos & Tercio & Vineyards & $\begin{array}{l}\text { Olive } \\
\text { orchards }\end{array}$ & Years $^{\mathrm{a}}$ \\
\hline 1750 & & & & & & & \\
$\mathrm{~N}$ & 9.3 & -13.6 & -3.6 & 0.7 & -3.7 & 15.2 & - \\
$\mathrm{P}$ & 16.7 & -3.1 & 0.8 & -0.6 & -1.1 & -1.2 & 668 \\
$\mathrm{~K}$ & -148.5 & 9.1 & -5.3 & -12.1 & -23.2 & -27.8 & 551 \\
1850 & & & & & & & \\
$\mathrm{~N}$ & 3.5 & -6.0 & 6.2 & 5.0 & -8.9 & 5.5 & - \\
$\mathrm{P}$ & -16.2 & -1.2 & -0.2 & -1.5 & -3.4 & -2.7 & 293 \\
$\mathrm{~K}$ & -274.0 & 13.0 & -7.4 & -17.2 & -53.4 & -53.2 & 452 \\
1900 & & & & & & & \\
$\mathrm{~N}$ & -13.4 & 6.1 & 2.1 & 0.1 & -8.9 & 4.3 & - \\
$\mathrm{P}$ & -22.4 & 3.6 & -0.4 & -1.4 & -3.5 & -2.9 & 271 \\
$\mathrm{~K}$ & -332.2 & 29.9 & -12.8 & -17.2 & -53.4 & -54.1 & 277 \\
\hline
\end{tabular}

a Years when olive growing would deplete soil reserves

Earlier, we associated the increasingly precarious situation of the peasantry in the late nineteenth century with the greater intensity in farming. According to our data, this association led to a process of soil degradation, which revealed itself in higher rates of erosion in the most expansive crop grown in southern Spain, olive orchards, and also in widespread nutrient mining that limited productive capacity. ${ }^{8}$

The negative balance registered in olive orchards continued to increase until the late nineteenth century. Although the balance of nitrogen was always positive, the mining of phosphorus and, to a greater extent, potassium increased. Although reserves of phosphorus and potassium were very high in the soil, the continued losses led to a long-term decline. According to García-Ruiz et al. (2012), the intensive levels of extraction practised in the late nineteenth century would have affected the production capacity of the olive orchards in a few decades.

In the final decades of the twentieth century, the availability of inexpensive synthetic fertilisers has spurred their uncontrolled use, especially for nitrogenous fertilisers. Over $60 \%$ of the nitrogen applied is not absorbed by the plant (Hermosín et al. 2009), and that nitrogen consequently causes significant water and soil contamination (Beaufoy 2001; Tombesi et al. 1996). In addition, this same management approach is responsible for the loss of ground cover plants and, therefore, the increased erosional processes in olive orchards (see following section).

\subsubsection{Soil Erosion in Olive Orchards: A Long-Term Perspective}

During previous research (see Vanwalleghem et al. 2011), we reconstructed soil losses in the olive orchards of Montefrío from 1750 until the present. This quant-

\footnotetext{
${ }^{8}$ We have documented elsewhere how this process has even caused a decline in yield (González de Molina et al. 2010).
} 
Table 7.5 Average soil losses (in t/ha/year) from the olive orchards of Montefrío for different periods, 1750-2000. A distinction is drawn between losses caused by tillage and water erosion. (Based on Vanwalleghem et al. 2011; Infante-Amate et al. 2013)

\begin{tabular}{lrll}
\hline & Tillage & Water & Total \\
\hline $1752-1856$ & 2.00 & 21.00 & 23.00 \\
$1856-1888$ & 7.71 & 39.77 & 47.48 \\
$1888-1896$ & 23.47 & 40.69 & 64.16 \\
$1896-1935$ & 20.12 & 30.48 & 50.60 \\
$1935-1950$ & 20.12 & 15.57 & 35.68 \\
$1950-1970$ & 10.06 & 15.57 & 25.62 \\
$1970-1990$ & 28.16 & 61.36 & 89.52 \\
$1990-2000$ & 6.50 & 84.26 & 90.76 \\
Average & 11.35 & 29.65 & 41 \\
\hline
\end{tabular}

ification was performed using measurements taken in three plots of land located within the town, following the methodology defined by Vanwalleghem et al. (2010). ${ }^{9}$

Table 7.5 shows the primary results, reflecting the average values for the three plots of land studied. ${ }^{10}$ The average soil losses (just over $40 \mathrm{t} / \mathrm{ha} / \mathrm{year}$ ) significantly exceeded the natural rate of soil regeneration (Montgomery 2007), but different values were observed over the course of the period studied. A clear upwards trend is observed from the lowest losses in the mid-eighteenth century to the present highest losses, with the exception of the mid-twentieth century when the losses declined.

Because the level of rainfall, the gradient, and soil type remained relatively stable throughout the period studied, the soil losses must be directly linked to changes in soil management. ${ }^{11}$

\footnotetext{
${ }^{9}$ This methodology allows us to the analyse changes in the soil height between the bases of tree trunks and the centres of the furrows between olive trees that are caused by water erosion and labour. Subsequently, soil losses caused by water erosion were estimated using RUSLE (Renard et al. 1997), adapted for olive orchards using the methodology proposed by Gómez et al. (2003); soil losses caused by labour were also estimated, applying the basic equations of this diffusive process (Van Oost et al. 2006) and considering the different olive orchard management approaches used over time. Thus, we have been able to differentiate between the soil losses linked to different processes for each plot of land studied. The experimental data obtained were used to calibrate the results of the model (for further details, see Vanwalleghem et al. 2011).

${ }^{10}$ See Fig. 7.1. The study sites correspond with the three places in the town where historic olive trees could be found, enabling application of the methodology of Vanwalleghem et al. (2010).

${ }^{11}$ Rainfall, slope gradient and soil type remained relatively stable throughout the studied period. Vanwalleghem et al. (2011) reconstructed rainfall trends for the study period based on a combination of instrumental and documentary records and concluded that there were no significant changes. Field observation of the soil profiles showed that, although approximately a third of the original soil thickness was lost, this did not yet affect productivity owing to the relatively thick original soils. Therefore, it can be safely concluded that soil type did not change drastically during the study period. Slope gradient has also remained more or less constant over time. Although small changes due to erosion and deposition are not to be excluded locally in areas of convex-concave catenas, most olive orchards are characterised by long, straight slope profiles, which are expected to have changed little in gradient.
} 
Fig. 7.1 Location of Montefrío in relation to larger regional towns and the location of the three studied plots of land (shaded grey on the map of the town)

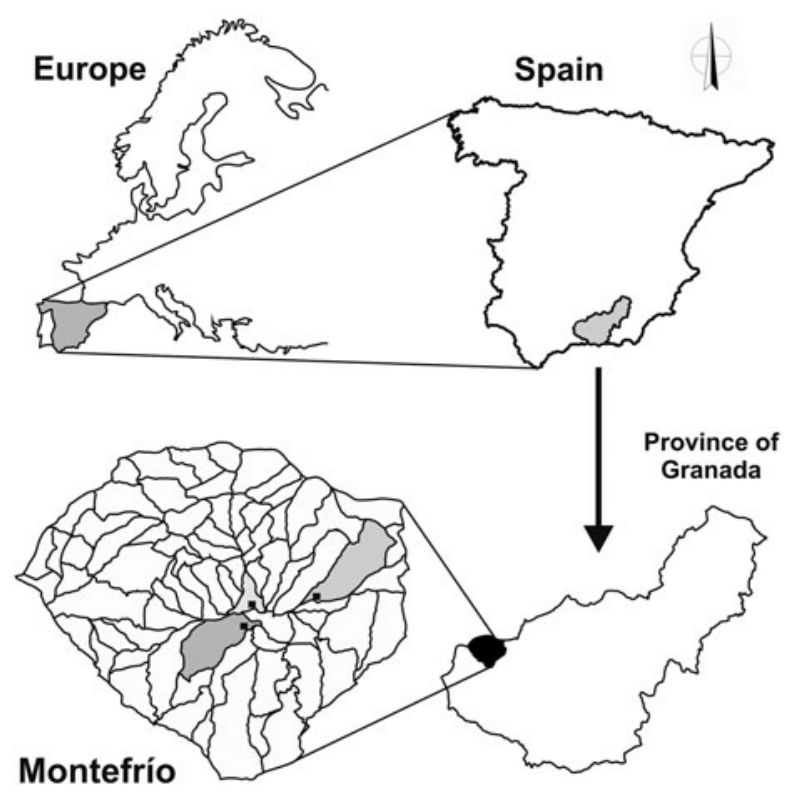

In the eighteenth century ${ }^{12}$, the olive orchards of Montefrío were barely tilled once a year, using a few people and animals. From the mid-nineteenth century onwards, with the new liberal reforms ${ }^{13}$ and subsequent demographic expansion, olive cultivation began to increase in the town. The sources describe greater intensity in soil management: the soil was tilled twice a year, between April and May, the bases of the olive tree trunks were dug out and, during the summer, manual reaping was replaced by very superficial tilling using harrow passes. In the late nineteenth century, the soil continued to be tilled at least twice a year, using more human and animal labour; hence, the soil remained bare for longer, and the risk of erosion consequently increased. This period also saw the introduction of the mouldboard plough. This technology penetrated the land even deeper, considerably increasing the risk of erosion.

From 1936 to 1975 , the management of olive orchards changed radically. The autarchic policies implemented during Franco's regime discouraged the production

\footnotetext{
${ }^{12}$ The historical sources used to reconstruct these tasks were fiscal, cadastral and oral. Information for the second half of the twentieth century was obtained through interviews. All of the details of these sources and descriptions of the management approaches can be found in Infante-Amate (2011) and Vanwalleghem et al. (2011). A general description of olive management and its relation to soil erosion can be found in Infante-Amate et al. (2013).

${ }^{13}$ This primarily involved dismantling the Ancien Regime through the suppression of privileges for the nobility and the clergy, the liberalisation of the land and labour market, repopulation policies and the suppression of monopolies. All of these changes entailed a major advance towards mercantile production and encouraged the rotation of lands through new owners and the promotion of crops such as olive trees.
} 
of olive oil (Tió 1982) and incentivised cereal crops (Christiansen 2002). Throughout the country, farmers sowed cereal crops between their rows of olive trees to alleviate these years of shortage, known as the "years of hunger". Therefore, paradoxically, soil losses under Francoism fell to historically low levels by increasing the amount of plant ground cover between olive trees.

The major change came in the early 1970s, when the use of tractors increased, replacing animal labour. The greater efficiency of mechanical traction enabled farmers to significantly increase tillage. At the beginning of the 1990s, another important change took place. Mouldboard ploughing, which was used during the spring to eliminate spontaneous ground cover, was replaced with the application of weed killers.

Comparing the soil loss in the olive orchards of Montefrío with the changing number of inhabitants of the town, we see that these two trends have not been parallel over the past two centuries. The common history of soil degradation and land use practices indicates that agriculture in Montefrío intensified as the population increased during the nineteenth century until significant soil losses occurred. In other words, in the context of pre-industrial production, there was a high correlation between population growth and erosion. This close coupling between population and soil degradation disappeared in the twentieth century. The institutional features of Francoism resulted in a drastic decline in soil erosion, while population size increased further; in the final decades of the twentieth century, soil degradation increased again to high levels because of the fast expansion and industrialisation of olive production at a time when demographic pressure reached historic lows.

Agronomic literature commonly points to soil degradation in olive orchards as one of the main environmental problems in this region (Beaufoy 2001; Gómez et al. 2008; Kirkby et al. 2004). However, in relation to the discussion here, it is worth examining the causes that precipitated this change. Was population pressure responsible? Figure 7.2 reveals that in recent decades, the number of inhabitants has been declining to all-time low figures, whereas soil degradation in olive orchards is achieving maximum levels. Boserupian analysis also proves to be insufficient here to account for the socio-ecological transition towards an industrial metabolic regime that occurred in Montefrío (Sieferle 2001).

\subsection{Conclusion: A Sociometabolic Approach to Agrarian Intensification and Soil Degradation}

Our case study demonstrates that soil degradation was changed over time, manifested with different levels of intensity and that there was no cause-effect relationship between productive intensification, which caused soil degradation, and population density. Intensification is better explained as a result of the "pressure of production on resources" (FAO 1995, p. 40), in other words, as a result of diverse socio-ecological factors. As Blaikie and Brookfield (1987, p. 4) said some time ago, it is "futile to search for a uni-causal model of explanation". Population continues to be one of the 


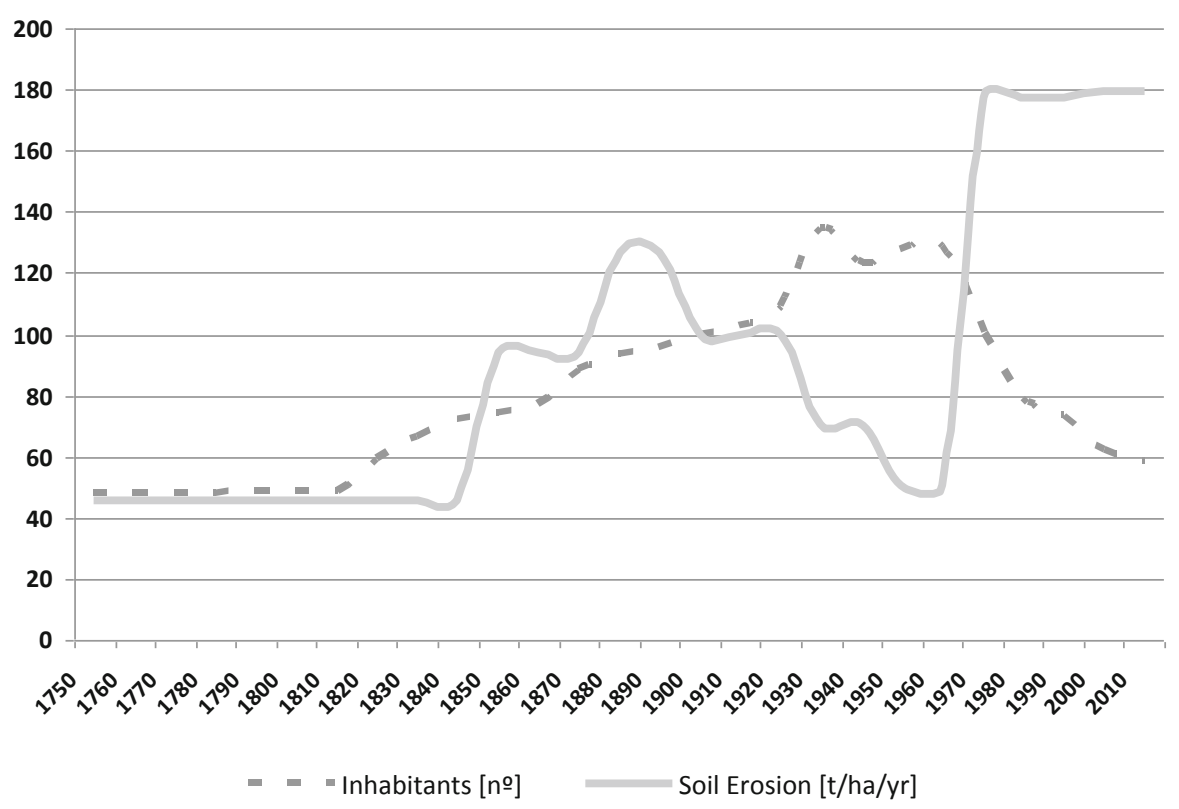

Fig. 7.2 Evolution of soil erosion rates in the olive orchards in Montefrío and town population (Index $1900=100)$. (Source: Infante-Amate et al. 2013)

core variables affecting the functioning of the social metabolism and, at the same time, one of the factors that drive its transformation; but population growth cannot be considered to be the independent variable that explains the behaviour of the other variables.

Fischer-Kowalski et al. (2010) have indicated that the theory of agrarian change developed by Boserup is linear insofar as it describes a continuous process of development or intensification from a pastoral model to intensive agriculture, ignoring the changes that occur, for example, in the energy base of the society. The aforementioned case study provided by the authors seems better explained by the theory of sociometabolic transition than by the classic Boserupian theory. With the increasing use of fossil fuels in agriculture, the Boserupian link between the declining productivity of labour and the increase in population density is annulled and replaced by the link between the increase in fossil energy and industrial technologies and the increase in labour productivity (Fischer-Kowalski et al. 2010, p. 33).

We agree with these authors that the theoretical proposal of the social metabolism provides the instruments required to adequately explain both the intensification of production and the levels of soil degradation, a metabolic relationship that is configured differently over time in accordance with three major regimes (Sieferle 2001) and different energy bases. In other words, soil degradation must be explained without a specific configuration of the agrarian metabolism or the transition process from one metabolism to another (Haberl et al. 2011, p. 4). This provides a way of reconciling Boserup and Malthus. They both shared the idea that at the very heart 
of socio-ecological change lies the relationship between the population and natural resources, although they understood the relationship between the two variables differently. This reconciliation must be founded on the acknowledgement that both the population and the stock of resources are mutually dependent.

The arguments proposed by Boserup should be expanded with two decisive contributions of the Malthusian tradition: on the one hand, the acknowledgement that natural resources are finite and that the possibilities for transformation are limited; and on the other hand, that social systems have not stopped growing since they first appeared. Precisely for that reason, reconciliation would entail assuming a more complex vision of population growth that does not only consider demographic components but also their level of consumption and the ways in which they relate to one another.

Ultimately, the intensification of production can lead to the generalisation of unsustainable management practices and, therefore, to soil degradation. However, this is not a linear process; instead, it responds to the conditions established in each metabolic regime. In this respect, the case study examined here allows us to identify two key phases in this process. The first phase was in the late nineteenth century, when erosion reached high levels, and nutrients were mined, which would have ensured sustainability in the medium term. The second phase was in the final few decades of the twentieth century, when soil losses were greatest and over-fertilisation appeared as one of the most serious environmental problems in the history of agriculture. The first phase was the result of the exhaustion of productive possibilities within a still organic or solar agrarian metabolic regime, which was therefore incapable of meeting the needs of the entire population, especially the poorest peasants. The agrarian liberal reforms favoured access to land for a very large group of peasants, and thus fostered population growth. Both factors, in the context of a solar energybased economy (Sieferle 2001), forced productive intensity ${ }^{14}$ to unsustainable levels. Although the development of a Boserupian strategy can be perceived over the course of the nineteenth century through the intensification of farming land, for example, by reducing fallow, this did not prevent the situation from later bordering on a Malthusian crisis, which resulted in sharp declines in biological standards of living and emigration (Cámara 2007).

In the late twentieth century, in contrast, within the context of an industrial metabolic regime and with a declining population, the pressure on the agro-ecosystem of Montefrío increased to levels hitherto unseen. The current economic situation of the sector, in which farmers are losing purchasing power, has been an incentive to opt for more invasive technologies, which in theory would allow them to multiply yields whilst saving on labour (Beaufoy 2001), following a pattern repeated elsewhere (Ananda and Herath 2003). The lack of adequate compensation for the costs derived from introducing plant cover also explains why the use of weed killers and the overuse of nitrogenous fertilisers continue to occur in spite of the negative effects on the soil.

\footnotetext{
${ }^{14}$ Understood as increases in management and primary production.
} 
However, there are sharp differences between these two phases. The first was the result of the exhaustion of productive possibilities under an organic metabolic regime, and its effects were limited by the capacity for intensification offered by this regime. The second was a structural result of the model of agrarian intensification imposed by the industrial metabolic regime, based on continued productive effort. The rate of erosion and the levels of nutrient degradation in the soil were also much higher due to the widespread use of fossil fuels.

In any case, these two critical phases of soil degradation created the conditions for the beginning of a transition towards another metabolic regime. In the first case, pressure on resources in the context of organic production could only be relieved through the transition towards an industrial model. Currently, now that soil degradation in olive orchards is becoming one of the most severe problems for European agriculture (Kirkby et al. 2004), the situation looks ripe for a new transition towards a more sustainable metabolic regime (Haberl et al. 2011).

Acknowledgments The authors would like to thank the staff at Montefrío Town Hall and the Oil Cooperative for their invaluable help compiling the information required for this article, in particular Antonio Guzmán, Felipe Jiménez and Isidro Cuevas. We would also like to thank Roberto García, Simone Gingrich, Fridolin Krausmann, Inma Villa and Verena Winiwarter for the useful comments they made on different versions of this paper. This article was made possible by the funding received for projects HAR2009-12936-C03-01 and HAR2009-13748-C03-03 (Spanish Ministry of Science and Innovation), P08-AGR-03925 (Andalusian Government), 895-2011-1020 (Canadian Social Sciences and Humanities Research Council) and through ERDF funding.

Open Access This chapter is distributed under the terms of the Creative Commons Attribution Noncommercial License, which permits any noncommercial use, distribution, and reproduction in any medium, provided the original author(s) and source are credited.

\section{References}

Allen, R. C. (2008). The nitrogen hypothesis and the English agricultural revolution: A biological analysis. The Journal of Economic History, 68, 182-210.

Analistas Económicos de Andalucía. (2000). El sector agrario en Andalucía, 1990-1991. Málaga. Spain: Unicaja.

Ananda, J., \& Herath, G. (2003). Soil erosion in developing countries: A socio-economic appraisal. Journal of Environmental Management, 68, 343-353.

Angles, S. (1999). The changes in the olive-growing geography of Andalusia. Olivae, 78, 12-22.

Beaufoy, G. (2001). EU policies for olive farming: Unsustainable on all counts. Brussels: BirdLife International, WWF.

Blaikie, P., \& Brookfield, H. (1987). Land degradation and society. London: Methuen.

Boserup, E. (1965). The conditions of agricultural growth: The economics of agrarian change under population pressure. New York: Aldine.

Boserup, E. (1981). Population and technological change: A study of long-term trends. Chicago: University of Chicago Press.

Cámara, A. D. (2007). Niveles de vida en el medio rural de Andalucía Oriental (1750-1950). Doctoral thesis, University of Granada, Spain. 
Christiansen, T. (2002). Intervención del Estado y mercado negro en el sector oleícola durante el primer franquismo. Historia Agraria, 27, 221-246.

Cruz, S. (1994). Caciques y campesinos: Poder politico, modernización agraria y conflictividad rural en Granada, 1890-1923. Madrid: Ediciones Libertarias.

Cunfer, G., \& Krausmann, F. (2009). Sustaining soil fertility: Agricultural practice in the old and new worlds. Global Environment, 4, 8-47.

Daly, H. (2005). Economics in a full world. Scientific American, 293, 100-107.

De Graaf, J., \& Eppink, L. A. A. J. (1999). Olive oil production and soil conservation in southern Spain, in relation to EU subsidy policies. Land Use Policy, 16, 259-267.

Erb, K., Krausmann, F., Lucht, W., \& Haberl, H. (2009). Embodied HANPP: Mapping the spatial disconnect between global biomass production and consumption. Ecological Economics, 69, 328-334.

FAO (Food and Agriculture Organization of the United Nations). (1983). Keeping the land alive. Soil erosion-its causes and cures (by H. W. Kelley). Soils Bulletin No. 50 Rome. Italy: FAO.

FAO (Food and Agriculture Organization of the United Nations). (1995). Population and land degradation. United Nations: Population Information Network, POPIN, September 1995.

FAO (Food and Agriculture Organization of the United Nations) (2013). FAOSTAT, FAO Statistical Databases. Production. http://faostat.fao.org/site/339/default.aspx. Accessed Feb 2013.

Fischer-Kowalski, M., Singh, S. J., Ringhofer, L., Grünbühel, C. M., Lauk, C., \& Remesch, A. (2010). Sociometabolic regimes in indigenous communities and the crucial role of working time: A comparison of case studies. Social Ecology Working Paper, 121. Vienna: IFF Social Ecology.

Fujita, M., Krugman, P., \& Venables, A. J. (1999). The spatial economy: cities, regions, and international trade. Cambridge: Massachusetts Institute of Technology (MIT).

García-Ruiz, R., González de Molina, M., Guzmán, G., Soto, D., \& Infante-Amate, J. (2012). Guidelines for constructing nitrogen, phosphorus and potassium balance in historical agricultural systems. Journal of Sustainable Agriculture, 36, 1-33.

Gómez, J. A., Battany, M., Renschler, C. S., \& Fereres, E. (2003). Evaluating the impact of soil management on soil loss in olive orchards. Soil Use and Management, 19, 127-134.

Gómez, J. A., Giráldez, J. V., \& Vanwalleghem, T. (2008). Comment on "Is soil erosion in olive groves as bad as often claimed?" by L. Fleskens and L. Stroosnijder. Geoderma, 147, 93-95.

González de Molina, M. (2010). A guideline to studying the socio-ecological transition in european agriculture. Sociedad Española de Historia Agraria, Docuementos de Trabajo, DT-SEHA, N. $10-06$.

González de Molina, M., \& Guzmán, G. (2006). Tras los pasos de la insustentagilidad. Agricultura $y$ medio ambiente en perspectiva histórica $(s . X V I I I-X X)$. Barcelona. Spain: Icaria.

González de Molina, M., García-Ruiz, R., Guzmán, G., Soto, D., \& Infante-Amate (2010). Guideline for constructing nutrient balances in historical agricultural systems (and its application to three cases-studies in Southern Spain). Sociedad Española de Historia Agraria, Documentos de Trabajo, DT-SEHA, N. 10-08.

González de Molina, M., Infante-Amate, J., Soto, D., \& Herrera, A. (2011). Desigualdad y crecimiento agrario. Sobre las consecuencias sociales de la reforma agraria liberal en Andalucía, 1752-1904. XIII Congreso de Historia Agraria, Sociedad Española de Historia Agraria, Lleida, May 2011.

Guzmán, G. I., \& González de Molina, M. (2009). Preindustrial agriculture versus organic agriculture. The land cost of sustainability. Land Use Policy, 26, 502-510.

Haberl, H., Fischer-Kowalski, M., Krausmann, F., Martinez-Alier, J., \& Winiwarter, V. (2011). A socio-metabolic transition towards sustainability? Challenges for another great transformation. Sustainable Development, 19, 1-14.

Hermosín, M. C., Rodríguez-Linaza, L. C., Cornejo, J., \& Ordóñez-Fernández, R. (2009). Efecto de uso de agroquímicos en el olivar sobre la calidad de las aguas. In J. A. Gómez (Ed.), Sostenibilidad de la producción de olivar en Andalucía (pp. 127-160). Sevilla: Consejería de Agricultura y Pesca. 
IEA (International Energy Agency) (2011). Sistema de Información Multiterritorial de Andalucía. Instituto de Estadística de Andalucía. http://www.juntadeandalucia.es/institutodeestadistica/ sima/. Accessed June 2011.

Infante-Amate, J. (2011). Ecology and history of the Andalusian olive grove: A socio-environmental study of the expansion of olive-growing in Andalusia. 18th-20th Centuries, Doctoral Thesis, University Pablo de Olavide, Spain.

Infante-Amate, J. (2012). The Ecology and history of the Mediterranean olive grove. The Spanish great expansion: 18th-20th Centuries. Rural History, 22, 161-184.

Infante-Amate, J., \& González de Molina, M. (2013). Sustainable de-growth in agriculture and food. An agro-ecological perspective on Spain's agri-food sector (year 2000). Journal of Cleaner Production, 38, 27-35.

Infante-Amate, J., González de Molina, M., Vanwalleghem, T., Soto, D., \& Gómez, J. A. (2013). Erosion in the Mediterranean: The case of olive groves in the South of Spain. Environmental History, 18, 360-382.

Kirkby, M. J., et al. (2004). Pan-European soil erosion risk assessment: the PESERA Map. Version of October 1, 2003. Explanation of Special Pub. Ispra 2004 No. 73 (S.P.I.04.73). European Soil Bureau Research Report No. 16 EUR 21176.

Martínez, M. (1995). Revolución liberal y cambio agrario en la Alta Andalucía. Granada, Spain: University of Granada.

McNeill, J. (1992). The mountains of the Mediterranean world: An environmental history. Cambridge: Cambridge University Press.

Montgomery, D. A. (2007). Soil erosion and agricultural sustainability. Proceedings of the National Academy of Sciences of the United States of America, 104, 13268-13272.

Renard, K. G., Foster, G. R., Weesies, G. A., McCool, D. K., \& Yoder, D. C. (1997). Predicting soil erosion by water: a guide to conservation planning with the revised universal soil loss equation (RUSLE). U.S. Dep. Agric., Agric. Handb. No. 703. Washington, DC: United States Department of Agriculture.

Sahlins, M. (1972). Stone age economics. New York: Aldine de Gruyter.

Sieferle, R. P. (2001). The subterranean forest: energy systems and the industrial revolution. Cambridge: The White Horse Press.

Tió, C. (1982). La política de aceites comestibles en la España del siglo XX. Madrid: Ministerio de Agricultura, Pesca y Alimentación.

Tombesi, A., Michelakis, N., \& Pastor, M. (1996). Recommendations of the working group on olive farming production techniques and productivity. Olivae 63. Madrid: International Olive Oil Council.

United Nations. (2007). World population prospects: The 2006 revision. New York: United Nations Population Division.

Van Oost, K., Govers, G., DeAlba, S., \& Quine, T. A. (2006). Tillage erosion: A review of controlling factors and implications for soil quality. Progress in Physical Geography, 30, 443-466.

Vanwalleghem, T., Laguna, A., Giráldez, J. V., \& Jiménez-Hornero, F. J. (2010). Applying a simple methodology to assess historical soil erosion in olive orchards. Geomorphology, 114, 294-302.

Vanwalleghem, T., Infante-Amate, J., González de Molina, M., Soto, D., \& Gómez, J. A. (2011). Quantifying the effect of historical soil management on soil erosion rates in olive orchards over the last 250 years. Agriculture, Ecosysmtems and Environment, 142, 341-351.

Würtenberger, L., Koellner, T., \& Binder, C. R. (2006). Virtual land use and agricultural trade: Estimating environmental and socio-economic impacts. Ecological Economics, 57, 679-697. 